\title{
Komposisi Jenis Gastropoda di Mangrove Desa Kaliwlingi dan Sawojajar, Jawa Tengah
}

\author{
Erik Wijaya Kusuma*, Ria Azizah Tri Nuraini, Retno Hartati \\ Departemen IImu Kelautan, Fakultas Perikanan dan IImu Kelautan, Universitas Diponegoro \\ JI. Prof H. Soedharto S H, Tembalang, Semarang, Jawa Tengah 50275 Indonesia \\ ${ }^{*}$ Corresponding author, e-mail : justerik80@gmail.com
}

\begin{abstract}
ABSTRAK : Desa Kaliwlingi dan Sawojajar mempunyai kawasan hutan mangrove dengan karakteristik berbeda. Kawasan hutan mangrove Kaliwlingi menjadi ekowisata mangrove sejak tahun 2016, sedangkan di Sawojajar merupakan kawasan mangrove alami. Perbedaan fungsi tersebut diduga dapat mempengaruhi keanekaragaman hayati yaitu salah satunya adalah gastropoda. Tujuan dari penelitian ini adalah untuk mengetahui struktur komunitas Gastropoda di ekosistem mangrove Desa Kaliwlingi dan Sawojajar, Kab.Brebes, Jawa Tengah. Pengambilan sampel dilakukan pada bulan Juni sampai Juli 2018. Penentuan titik sampling menggunakan metode purposive pada 3 stasiun dengan tiga kali pengulangan. Hasil penelitian menunjukan terdapat 2 subkelas yaitu Pulmonata dan Prosobranchiata, dengan 3 famili dan 9 spesies gastropoda dari 3 famili, yaitu Elliobidae; Cassidula aurisfelis (Elliobidae), C. nucleus (Elliobidae), Littoraria articulate (Littorinidae), L. carinifera (Littorinidae), L. melanostoma (Littorinidae), L. scabra (Littorinidae), Telescopium telescopium (Potamididae), Terebralia obtuse (Potamididae), $T$. palustris (Potaminidae). Nilai kelimpahan rata-rata gastropoda Desa Kaliwlingi dan Desa Sawojajar masing-masing 20,28 dan 16,36 ind $/ \mathrm{m}^{2}$. Indeks Keanekaragaman ( $\mathrm{H}^{\prime}$ ) gastropoda di kawasan mangrove Desa Kaliwlingi dan Desa Sawojajar termasuk ke dalam kategori rendah ke tinggi, sedangkan indeks keseragamannya berkategori rendah. Tidak ada jenis gastropod yang mendominasi di kawasan mangrove Kaliwlingi dan Sawojajar, dengan pola sebaran gastropoda mengelompok.
\end{abstract}

Kata Kunci : Mangrove; Gastropoda; Brebes

\section{Abundance and Composition Gastropods in Mangrove Ecosystems Kaliwlingi and Sawojajar Villages, Central Java}

ABSTRACT: Kaliwlingi and Sawojajar villages have mangrove forest areas with different characteristics. The Kaliwlingi mangrove forest area has been established as mangrove ecotourism since 2016, while in Sawojajar it is a natural mangrove area. The difference in function is thought to affect biodiversity, one of which is gastropods. The purpose of this study was to determine the structure of the Gastropoda community in the mangrove ecosystems of Kaliwlingi and Sawojajar Villages, Kab. Brebes, Central Java. Sampling was conducted in June to July 2018. Determination of the sampling points using purposive methods at 3 stations with three repetitions. The results showed that there were 2 subclasses, namely Pulmonata and Prosobranchiata, with 3 families and 9 gastropod species from 3 families, namely Elliobidae; Cassidula aurisfelis (Elliobidae), C. nucleus (Elliobidae), Littoraria articulate (Littorinidae), L. carinifera (Littorinidae), L. melanostoma (Littorinidae), L. scabra (Littorinidae), Telescopium telescopium (Potamebidide)), $T$. palustris (Potaminidae). The mean abundance of gastropods in Kaliwlingi Village and Sawojajar Village were 20.28 and 16.36 Ind / $\mathrm{m}^{2}$ respectively. Diversity Index ( $H^{\prime}$ ) of gastropods in the mangrove areas of Kaliwlingi Village and Sawojajar Village are in the low to high category, while the uniformity index is categorized as low. There is no type of gastropod that dominates in the Kaliwlingi and Sawojajar mangrove areas, and gastropod distributed as a grouped.

Keywords: Gastropods; Composition; Brebes

\section{PENDAHULUAN}

Terdapat 3,3, juta hektar hutan mangrove di Indonesia, salah satu ekosistem mangrove yang berada di pulau Jawa adalah di pesisir Kabupaten Brebes (BPS, 2016). Brebes memiliki garis 
pantai sepanjang $53 \mathrm{Km}$ yang berpotensi dimanfaatkan dalam bidang pariwisata, khususnya obyek wisata hutan mangrove. Obyek wisata hutan mangrove yang saat ini berkembang adalah wisata hutan mangrove Pandansari (Dewi Mangrove Sari) yang terletak di Desa Kaliwlingi Kecamatan Brebes. Obyek wisata hutan mangrove terbentuk setelah ada kegiatan rehabilitasi yang dimulai tahun 2005 sebagai bentuk antisipasi terhadap adanya abrasi seluas 650,54 ha pada tahun 20002008 (Badan Perencanaan Pembangunan Penelitian dan Pengembangan Daerah Kabupaten Brebes, 2018). Dampak positif adanya rehabilitasi adalah adanya penambahan lahan mangrove seluas 815,76 ha pada tahun 2008 (Annisa et al., 2019), sehingga luas keseluruhan hutan mangrove di Desa Kaliwlingi bertambah dari 101,25 ha pada tahun 2008 menjadi 149,67 ha pada tahun 2013. Dari kegiatan rehabilitasi ini, lokasi tersebut menjadikan daerah ekowisata mangrove. Ekowisata dibuka pada tahun 2016 dan pengunjung semakin meningkat seiring berjalannya waktu yaitu 35.000 orang. Kegiatan ini diduga dapat berdampak terhadap kawasan mangrove dan biota yang hidup di dalamnya.

Gastropoda merupakan salah satu kelompok fauna avertebrata yang hidup di ekosistem mangrove (Nontji, 1993). Gastropoda sebagai salah satu mata rantai makanan ekosistem mangrove, selain sebagai pemangsa detritus dalam proses dekomposisi serasah, juga berperan sebagai herbivor yang memakan tumbuh-tumbuhan dan detritivor pemakan material organik (Irwanto, 2006). Tujuan penelitian ini adalah untuk mengetahui struktur komunitas gastropoda di kawasan mangrove Desa Kaliwlingi dan Sawojajar, Kabupaten Brebes.

\section{MATERI DAN METODE}

Materi yang diteliti adalah gastropoda yang ditemukan di kawasan mangrove Desa Kaliwlingi dan Sawojajar, Kabupaten Brebes (Gambar 1). Terdapat tiga stasiun pada tiap lokasi, yaitu KW1, KW2 dan KW3 di Desa Kaliwlingi dan SW1, SW2 dan SW3 di Desa Sawojajar, tap stasiun terdapat tiga (3) plot pengamatan. Metode yang digunakan dalam penelitian ini adalah deskriptif, sedangkan pengambilan sampel gastropoda dilakukan dengan metode Sasekumar (1974), yaitu secara kualitatif menggunakan plot $5 \mathrm{~m} \times 5 \mathrm{~m}$ dengan hand picking. Sampel gastropoda dimasukkan ke dalam botol sampel dan diawetkan dengan larutan formalin 10\% untuk pengawetan. Di Laboratorium Biologi Kelautan, Departemen IImu Kelautan FPIK UNDIP, sampel gastropoda di identifikasi berdasarkan Dharma (1992); Carpenter dan Niem (1998). Sampel yang telah dicuci dan disortir kemudian diawetkan di dalam botol sampel, kemudian dari setiap kelompok diambil perwakilan untuk difoto, dan diidentifikasi jenis spesies gastropoda. Identifikasi gastropoda dengan cara mengamati ciri-ciri morfologi struktur cangkang gastropoda (apex, spire, body whorl, suture, aperture, axial ribs, spiral cord, columella, posterior canal, anterior siphotal canal, dan operculum). Identifikasi melalui warna cangkang gastropoda tidak dapat dilakukan karena warna cangkang gastropoda setiap individunya berbeda. Perbedaan warna dari cangkang pada setiap gastropoda disebabkan oleh kemampuan adaptasi individu yang berbeda (Barnes dan Rupert, 1994).

Pada saat pengambilan sample gastropoda, sampel sedimen juga diambil untuk dilakukan analisis kandungan bahan organik dan ukuran butir. Analisis sedimen dilakukan di Laboratorium Kimia Analitik Fakultas Sains Matematika dan Laboratorium Mekanika Tanah Fakultas Teknik, Universitas Diponegoro. Analisis grain size dilakukan dengan metode dry sieving (pengayakan) dan wet sieving (pemipetan) (Buchanan, 1984). Parameter lingkungan yang di ukur meliputi salinitas, $\mathrm{pH}$, suhu dan DO yang dilakukan secara langsung (in situ). Kelimpahan jenis gastropoda dihitung dengan rumus Odum (1993):

$$
\mathrm{A}=X i / n i
$$

Keterangan : $\mathrm{A}=$ Kelimpahan (jumlah ind $/ 25 \mathrm{~m}^{2}$ ); $\mathrm{Xi}=$ Jumlah individu; $\mathrm{Ni}=$ luasan kuadrat

Keanekaragaman jenis gastropoda dihitung dengan Indeks Keanekaragaman ShannonWeaner (Odum,1993) :

Keterangan: $H^{\prime}=$ Indeks keanekaragaman; $\pi:(n i / N)$

$$
H^{\prime}=-\sum \pi \log 2 \pi
$$


Menurut Wilhm (1975) kriteria Indeks Keanekaragaman dibagi menjadi 3, yaitu, $H^{\prime}<1,0=$ keanekaragaman jenis rendah; $1,0<\mathrm{H}^{\prime}<3=$ keanekaragaman jenis sedang; $H^{\prime}>3=$ keanekaragaman jenis tinggi. Indeks Keseragaman jenis gastropoda dihitung menurut Odum (1993):

$$
E=H^{\prime} / \log S
$$

Keterangan : $\mathrm{E}=$ Indeks Keseragaman; $\mathrm{H}^{\prime}=$ Indeks Keanekaragaman; $\mathrm{S}=$ Jumlah jenis

Indeks keseragaman menurut Krebs (1989) berkisar antara 0-1, dimana: 0,6-1= Keseragaman spesies tinggi; $0,4<\mathrm{E}<0,6=$ Keseragaman spesies sedang; $0-0,4=$ Keseragaman spesies rendah. Indeks Dominansi dihitung menggunakan rumus Simpson (Odum, 1993):

$$
\mathrm{C}=\sum\left(\frac{X i}{N}\right)^{2}
$$

Keterangan $: \mathrm{C}=$ Indeks dominansi; $\mathrm{Xi}=$ Nilai penting untuk tiap spesies; $\mathrm{N}=$ Total seluruh individu ditemukan

Pola sebaran jenis gastropoda dihitung menurut Krebs (1989), yaitu

$$
\mathrm{ID}=\mathrm{n}\left\{\frac{\sum X \boldsymbol{X} \mathbf{X} \mathrm{Xi}-\sum X \boldsymbol{X}}{\left(\sum X \mathbf{X} \mathbf{X}\right)-\sum \boldsymbol{X} \boldsymbol{i}}\right\}
$$

Keterangan : ID = Indeks dispersi morisita; $X \mathbf{i}=$ jumlah total unit samping; $\sum \boldsymbol{X} \boldsymbol{i}=$ Jumlah total jenisi $\sum \boldsymbol{X} \boldsymbol{i} . \boldsymbol{X} \boldsymbol{i}=$ Jumlah jenis ke $\mathrm{i}$

Kriteria pola sebaran jenis yaitu sebagai berikut: ID $=0=$ pola sebaran random atau acak $(R)$; $I D>0$ = pola sebaran mengelompok atau clumped $(C) ; I D<0=$ Pola sebaran teratur atau Uniform (U).

\section{HASIL DAN PEMBAHASAN}

Hasil penelitian ini menemukan 9 spesies gastropoda di kawasan mangrove Kaliwlingi dan Sawojajar, Kabupaten Brebes, yang termasuk 3 famili, yaitu : Cassidula aurisfelis (Elliobidae), $C$. nucleus (Elliobidae), Littoraria articulate (Littorinidae), L. carinifera (Littorinidae), L. melanostoma (Littorinidae), L. scabra (Littorinidae), Telescopium telescopium (Potamididae), Terebralia obtuse (Potamididae), T. palustris (Potaminidae). Jenis-jenis gastropoda yang ditemukan di kedua kawasan mangrove disajikan pada Tabel 1. Famili yang paling banyak ditemukan di lokasi penelitian adalah famili Littorinidae diwakili oleh 4 spesies gastropoda yaitu $L$. articulate, $L$. carnifera, L. melanostoma dan L. scabra. Kawasan mangrove yang di pengaruhi pasang surut
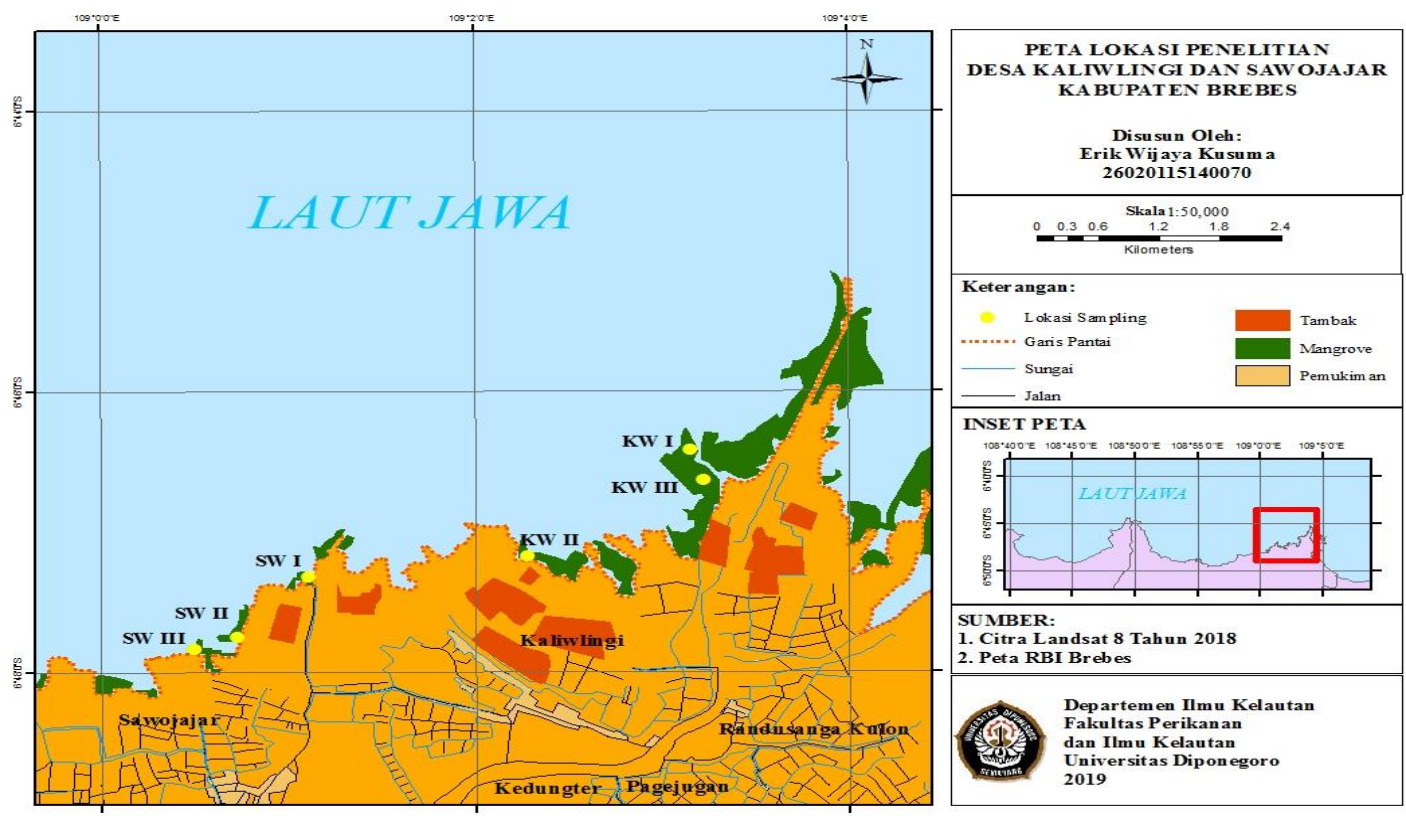

Gambar 1. Peta lokasi pengambilan sampel gastropoda pada Vegetasi Mangrove Desa Kaliwlingi dan Sawojajar, Kabupaten Brebes Jawa Tengah. 
Tabel 1. Komposisi Gastropoda yang Ditemukan di kawasan mangrove Desa Kaliwlingi (KW) dan Sawojajar (SW), Brebes

\begin{tabular}{|c|c|c|c|c|c|c|c|c|c|c|c|}
\hline \multirow{2}{*}{ No. } & \multirow{2}{*}{ Famili } & \multirow{2}{*}{ Spesies } & \multicolumn{3}{|c|}{ KW I } & \multicolumn{3}{|c|}{ KW II } & \multicolumn{3}{|c|}{ KW III } \\
\hline & & & 1 & 2 & 3 & 1 & 2 & 3 & 1 & 2 & 3 \\
\hline 1 & Ellobiidae & Cassidula aurisfelis & + & + & + & + & + & + & + & + & + \\
\hline 2 & Ellobiidae & Cassidula nucleus & + & + & + & + & + & + & + & + & + \\
\hline 3 & Littorinidae & Littoraria articulata & + & + & + & + & + & + & + & + & + \\
\hline 4 & Littorinidae & Littoraria carinifera & + & + & - & + & + & + & + & - & + \\
\hline 5 & Littorinidae & Littoraria melanostoma & + & + & - & + & + & + & + & + & + \\
\hline 6 & Littorinidae & Littoraria scabra & + & + & + & + & + & - & - & + & + \\
\hline 7 & Potamididae & Telescopium telescopium & + & - & - & + & + & - & - & + & - \\
\hline 8 & Potamididae & Terebralia obtusa & + & - & - & + & + & - & + & + & - \\
\hline 9 & Potamididae & Terebralia palustris & + & + & - & + & + & + & + & + & + \\
\hline \multicolumn{2}{|c|}{ Jumlah Species } & \multirow{3}{*}{ Spesies } & 8 & 7 & 4 & 9 & 9 & 6 & 7 & 8 & 8 \\
\hline \multirow{2}{*}{ No. } & \multirow{2}{*}{ Famili } & & \multicolumn{3}{|c|}{ SW I } & \multicolumn{3}{|c|}{ SW II } & \multicolumn{3}{|c|}{ SW III } \\
\hline & & & 1 & 2 & 3 & 1 & 2 & 3 & 1 & 2 & 3 \\
\hline 1 & Ellobiidae & Cassidula aurisfelis & + & + & + & + & + & + & + & + & + \\
\hline 2 & Ellobiidae & Cassidula nucleus & + & + & + & + & + & + & + & + & + \\
\hline 3 & Littorinidae & Littoraria articulata & + & + & + & + & + & + & + & + & + \\
\hline 4 & Littorinidae & Littoraria carinifera & + & + & + & + & + & + & + & + & + \\
\hline 5 & Littorinidae & Littoraria melanostoma & - & + & + & + & - & - & - & - & - \\
\hline 6 & Littorinidae & Littoraria scabra & - & + & + & - & - & + & + & + & + \\
\hline 7 & Potamididae & Telescopium telescopium & + & - & - & + & + & - & + & - & + \\
\hline 8 & Potamididae & Terebralia obtusa & + & + & - & + & + & - & + & + & + \\
\hline 9 & Potamididae & Terebralia palustris & + & + & + & + & + & + & + & + & + \\
\hline \multicolumn{3}{|c|}{ Jumlah Species } & 8 & 7 & 7 & 7 & 8 & 8 & 7 & 8 & 7 \\
\hline
\end{tabular}

merupakan habitat yang baik bagi gastropoda ini. Plaziat (1984), menambahkan bahwa genus Littorina cenderung berasosiasi dengan Rhizophora, Avicennia, Sonneratia dan Mangrove lainya. Famili Potamididae diwakili oleh 3 spesies yaitu $T$. telescopium, C. obtuse dan T. palustris. Menurut Carpenter dan Niem (1988), family potamididae ini ditemukan melimpah pada daerah yang berair payau, daerah estuaria yang berlumpur dan daerah mangrove atau rawa dekat garis pasang tertinggi.

Kelimpahan gastropoda di kawasan mangrove Desa Kaliwlingi $(\mathrm{KW})$ sebesar 20,28 $\mathrm{Ind} / \mathrm{m}^{2}$ lebih tinggi daripada Desa Sawojajar (SW) yaitu sebesar $16,36 \mathrm{Ind} / \mathrm{m}^{2}$. Hal ini diduga karena wilayah penelitian Desa Kaliwlingi merupakan wilayah rehabilitasi mangrove sehingga memilki jenis mangrove yang beranekaragam dan kerapatan mangrove yang lebih tinggi dibandingkan Desa Sawojajar. Stasiun KW II memilki kerapatan mangrove $5.567 \mathrm{Ind} / \mathrm{ha}$, nilai kerapatan mangrove pada KW I sebesar 2.200 Ind/ha, dan nilai kerapatan mangrove pada KW III sebesar $1.733 \mathrm{Ind} / \mathrm{ha}$.

Rata-rata kelimpahan gastropoda di kawasan mangrove Desa Kaliwlingi dan Sawojajar bervariasi diduga karena kondisi lingkungan yang berbeda dan letak stasiun yang berbeda sehingga mempengaruhi nilai kelimpahan gastropoda. Dapat dilihat bahwa kondisi substrat pada lokasi penelitian menunjukan lanau berpasir, lempung berlanau, lanau berpasir dan pasir berlanau. Gastropoda cenderung memilih substrat lanau karena memiliki kadar oksigen yang sedikit, oleh sebab itu organisme yang hidup didalamnya akan beradaptasi. Jenis mangrove yang di temukan di lokasi Kaliwlingi yaitu Rhizophora mucronata, Avicennia alba dan A. marina, dengan kondisi substrat lanau berpasir. Menurut Nento et al. (2013), gastropoda menyukai hidup di substrat lanau berpasir. Jenis substrat berpasir memiliki pasokan oksigen yang tinggi, hal ini disebabkan karena 
teksturnya pasir terdapat pori-pori sehingga memungkinkan untuk oksigen pada air masuk ke dalam substrat. Menurut Ernanto et al., (2010), selain sebagai tempat hidup, substrat juga sebagai sumber makanan bagi sebagian besar hewan benthos. Bahan organik yang di peroleh pada lokasi penelitian yaitu 11,58 \% (KW I), 19,36 \% (KW II) dan 7,22\% (KW III). Melimpahnya bahan makanan untuk gastropoda yang berasal dari serasah mangrove karena vegetasi mangrove merupakan salah satu penghasil bahan organic yang berasal dari serasah mangrove yang kemudian di jadikan sebagai sumber makanan bagi biota yang hidup di dalamnya termasuk gastropoda (Hutama et al., 2019).

Rata-rata kelimpahan gastropoda pada Desa Sawojajar sebesar $16,36 \mathrm{Ind} / \mathrm{m}^{2}$ dan lebih rendah daripada Desa Kaliwlingi $\left(20,28 \mathrm{Ind} / \mathrm{m}^{2}\right)$, hal ini dikarenakan pada wilayah Desa Sawojajar merupakan daerah mangrove alami dengan kerapatan mangrove sedang dibandingkan Desa Kaliwlingi. Kerapatan mangrove di Desa Sawojajar pada Stasiun SW I, II dan II, masing-masing sebesar 2.533; 2.500 dan 2.333 ind/ha hidup pada kawasan mangrove jenis $A$. marina, $A$. alba dan $R$. mucronata. Desa Sawojajar memiliki subtrat lanau berpasir dengan bahan organik lebih tinggi dari pada Kaliwlingi yaitu sebesar 17,74 \% (SW I), 23,80 \% (SW II) dan 20,09 \% (SW III). Hal ini diduga letak lokasi penelitian lebih dekat dengan laut di bandingkan wilayah Kaliwlingi, sehingga memungkinkan wilayah Sawojajar lebih sering dan lama tergenang air pasang sehingga bahan organik yang terbawa air akan mengendap ke sedimen. Hasil ini selaras dengan Maslukah et al. (2014), bahwa arus pasang surut mempengaruhi pola penyebaran bahan organik. Pada saat pasang bahan organik menyebar lebih luas dibanding saat surut.

Nilai rata-rata Indeks Keanekaragaman $\left(\mathrm{H}^{\prime}\right)$ gastropoda di kawasan mangrove Desa Kaliwlingi dan Desa Sawojajar yang secara umum termasuk ke dalam kategori rendah sampai sedang, namun nilai indeks keanekaragaman Desa Kaliwlingi lebih tinggi daripada Desa Sawojajar. Diduga karena Desa Kaliwlingi memiliki kerapatan mangrove lebih tinggi yaitu berkisar 1.733-5.567 ind/ha yang dapat mempengaruhi keanekaragaman gastropoda yang mempunyai habitat berbeda-beda. Sedangkan pada Desa Sawojajar memiliki kerapatan mangrove berkisar 2.333-2.533 Ind/ha. Nybakken (1992) mengatakan bahwa jika dalam suatu komunitas memiliki nilai keanekaragaman sedang maka akan terjadi suatu interaksi antar spesies yang menimbulkan kompetisi, produktivitas cukup, kondisi ekosistem yang cukup seimbang dan tekanan ekolodis yang sedang. Menurut Odum (1993), nilai indeks keanekaragaman dipengaruhi oleh banyaknya jenis dan merata atau tidaknya nilai kelimpahan individu tiap jenis.

Indeks Keseragaman (e) gastropoda di kawasan mangrove Desa Kaliwlingi termasuk dalam kategori tinggi. Indeks Keseragaman (e) Desa Sawojajar termasuk dalam kategori rendah. Secara keseluruhan nilai indeks keseragaman menunjukan nilai yang bervariasi namun tetap dalam kategori yang sama yaitu rendah ke tinggi. Penyebab dari bervariasinya nilai indeks kesamaan adalah faktor parameter lingkungan yang bervariasi. Menurut Nybakken (1992), faktor lingkungan biotik maupun abiotik akan mempengaruhi kelimpahan dan keseragaman spesies biota di suatu lingkungan. Indeks keseragaman memiliki nilai rendah diduga karena spesies yang sedikit dan apabila memiliki nilai yang tinggi maka menunjukan kesamaan komunitas spesies yang besar, artinya kelimpahan dari tiap spesies tertentu lebih kecil. Menurut Wilhm dan Dorris (1986), semakin kecil nilai keseragaman jenis maka semakin kecil pula nilai keseragaman komunitas tersebut. Artinya penyebaran jenis dan jumlah individu tidak sama dan ada kecenderungan suatu komunits di dominasi oleh jenis tertentu, begitu pula sebaliknya. Nilai indelk keanekaragaman, keseragaman dan dominansi gastropoda di kawasan mangrove Desa Kaliwlingi dan Sawojajar dusajikan pada Tabel 1.

Berdasarkan nilai Indeks Dominasi gastropoda di Desa Kaliwlingi dan Sawojajar, Nampak tidak ada jenis gastropoda yang mendominasi. Menurut Syamsurial (2011), nilai indeks dominasi yang tinggi menyatakan konsentrasi dominan yang tinggi (ada individu yang mendominasi), sebaliknya jika indeks dominasi rendah maka menyatakan konsentrasi rendah (tidak ada yang mendominasi). Menurut Odum (1993), semakin kecil Indeks Keseragaman menunjukan penyebaran individu setiap spesies tidak sama dan terdapat kecenderungan adanya dominasi oleh spesies tertentu.

Gastropoda di kawasan mangrove Desa Kaliwlingi dan Sawojajar pada umumnya menunjukkan pola sebaran jenis yang mengelompok/Clumped dengan nilai berkisar 0,16-3,00 (ID>0) (Krebs, 1989). Hanya T. palustris ditemukan secara random di kawasan mangrove Desa 
Sawojajar Stasiun 3. Pola sebaran gastropoda secara lengkap disajikan pada Tabel 3. Adanya pola sebaran akan membantu memberikan gambaran struktur komunitas pada hewan yang berhabitat di mangrove. Menurut Krebs (1989) pola sebaran dapat dipengaruhi oleh sebaran pakan dalam waktu dan ruang serta kompetisi di dalam pemanfaatan sumberdaya habitat dan juga disebabkan oleh perubahan kondisi lingkungan.

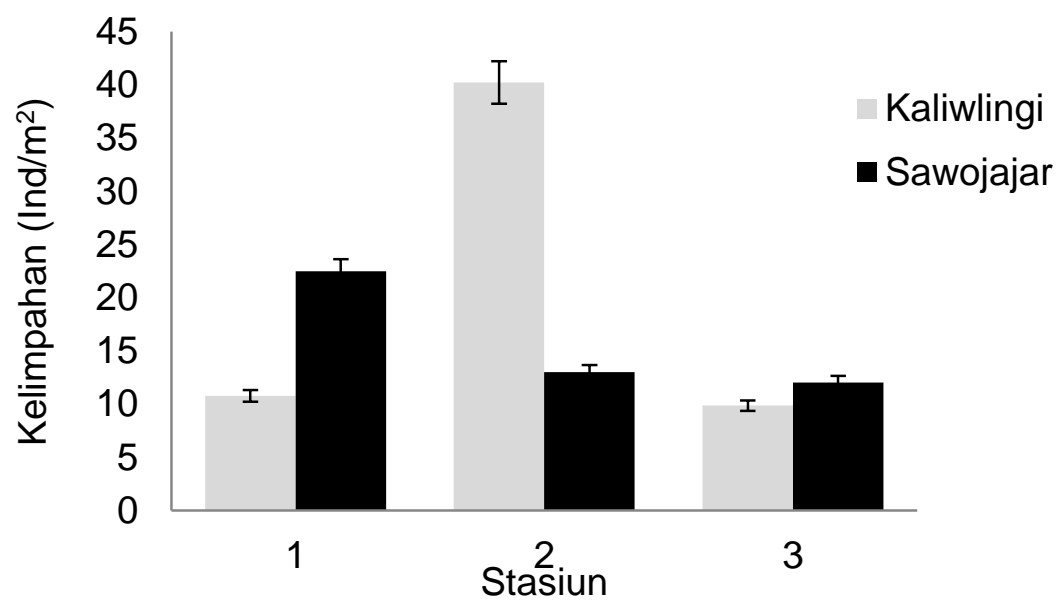

Gambar 2. Kelimpahan Gastropoda $\left(\mathrm{Ind} / \mathrm{m}^{2}\right)$ di kawasan mangrove Desa Kaliwlingi dan Desa Sawojajar, Brebes

Tabel 2. Indeks Keanekaragaman, Indeks Keseragaman, dan Indeks Dominasi Gastropoda pada kawasan mangrove Desa Kaliwlingi dan Sawojajar, Brebes

\begin{tabular}{llcccccc}
\hline \multirow{2}{*}{ Lokasi } & \multirow{2}{*}{ Stasiun } & \multicolumn{2}{c}{ Keanekaragaman } & \multicolumn{2}{c}{ Keseragaman } & \multicolumn{2}{c}{ Dominasi } \\
\cline { 3 - 7 } & & $\mathrm{H}^{\prime}$ & Kategori $^{*}$ & $\mathrm{e}$ & Kategori & C & Kategori $^{* * *}$ \\
\hline Kaliwlingi & KW I & 3,92 & Tinggi & 4,11 & Tinggi & 0,23 & TAD \\
& KW II & 2,52 & Sedang & 2,64 & Tinggi & 0,18 & TAD \\
& KW III & 0,23 & Rendah & 0,24 & Rendah & 0,21 & TAD \\
\hline \multirow{2}{*}{ Sawojajar } & SW I & 0,47 & Rendah & 0,49 & Sedang & 0,21 & TAD \\
& SW II & 0,50 & Rendah & 0,52 & Sedang & 0,22 & TAD \\
& SW III & 0,54 & Rendah & 0,56 & Sedang & 0,25 & TAD \\
\hline
\end{tabular}

Tabel 3. Pola sebaran gastropoda di kawasan mangrove pada kawasan mangrove Desa Kaliwlingi dan Sawojajar, Brebes

\begin{tabular}{clccccccccccccc}
\hline No. & Spesies & \multicolumn{1}{c}{ KW1 } & \multicolumn{1}{c}{ KW2 } & \multicolumn{3}{c}{ KW3 } & \multicolumn{2}{c}{ SW1 } & \multicolumn{3}{c}{ SW2 } & \multicolumn{2}{c}{ SW3 } \\
\hline 1 & C. aurisfelis & 1,29 & C & 0,93 & C & 0,78 & C & 0,89 & C & 0,47 & C & 8,37 & C \\
2 & C. nucleus & 1,12 & C & 0,93 & C & 0,68 & C & 0,85 & C & 1,80 & C & 7,86 & C \\
3 & L. articulate & 0,32 & C & 0,92 & C & 0,50 & C & 0,84 & C & 0,15 & C & 0,18 & C \\
4 & L. carinifera & 0,36 & C & 0,35 & C & - & - & 0,60 & C & 0,22 & C & - & - \\
5 & L. & 0.29 & C & 0,16 & C & 2,79 & C & 3,66 & C & 2,28 & C & - & - \\
& melanostoma & & & & & & & & & & & & \\
6 & L. scabra & - & - & 0,34 & C & - & - & 0,12 & C & 0,29 & C & - & - \\
7 & T. telescopium & 0,73 & C & 1,23 & C & 3,00 & C & 3,00 & C & 0,30 & C & 0,27 & C \\
8 & C. obtuse & 3,00 & C & 0,79 & C & 1,00 & C & 0,11 & C & 0,28 & C & 2,89 & C \\
9 & T. palustris & 0,26 & C & 0,79 & C & 2,26 & C & 0,69 & C & 0,26 & C & 0,00 & R
\end{tabular}

Keterangan: $(-)=$ tidak ditemukan, $(\mathrm{C})=$ Clumped,$(\mathrm{R})=$ Random 


\section{KESIMPULAN}

Komposisi gastropoda yang ditemukan pada penelitian ini terdapat 9 spesies yang berasal dari 3 famili, yaitu : C. aurisfelis (Elliobidae), C. nucleus (Elliobidae), L. articulate (Littorinidae), L. carinifera (Littorinidae), L. melanostoma (Littorinidae), L. scabra (Littorinidae), T. telescopium (Potamididae), T. obtuse (Potamididae), T. palustris (Potaminidae). Kelimpahan rata-rata gastropoda pada desa Kaliwlingi lebih besar dari pada Desa sawojajar sebesar 20,28 Ind/ $/ \mathrm{m}^{2}$ dan $16,36 \mathrm{Ind} / \mathrm{m}^{2}$. Secara keseluruhan Indeks Keanekaragaman masuk dalam kategori rendah hingga tinggi $\left(H^{\prime}=0,23-3,92\right)$. Indeks Keseragaman termasuk dalam kategori rendah-tinggi $(E=0,24-$ $4,11)$. Indeks Dominasi termasuk ke dalam tidak ada jenis yang mendominasi.

\section{UCAPAN TERIMA KASIH}

Artikel ini merupakan bagian dari skripsi yang berjudul "Struktur Komunitas Gastropoda di Desa Kaliwlingi dan Sawojajar, Kec. Brebes, Kab. Brebes, Jawa Tengah" untuk memperoleh gelar Sarjana Strata Satu Program Studi IImu Kelautan, Fakultas Perikanan dan Ilmu Kelautan, Universitas Diponegoro

\section{DAFTAR PUSTAKA}

Annisa, A.Y.N., Pribadi, R.\& Pratikto, I. 2019. Analisis Perubahan Luasan Hutan Mangrove di Kecamatan Brebes dan Kecamatan Wanasari Menggunakan Citra Satelit Landsat Tahun 2008, 2013 dan 2018. Journal of Marine Research. 8(1):27-35.

Badan Perencanaan Pembangunan Penelitian dan Pengembangan Daerah; dan Dinas Penanaman Modal dan Perizinan Terpadu Satu Pintu. 2018. Proposal Proyek Investasi, Pengembangan Ekowisata Hutan Mangrove Dukuh Pandansari Desa Kaliwlingi Kecamatan Brebes Kabupaten Brebes.

Badan Pusat Statistik (BPS), 2016. Badan Pusat Statistik Jawa Tengah. https://jateng.bps.go.id/statictable/2017/10/27/1553/luas-penggunaan-lahan-dan-luaskawasan-hutan-menurut-kabupaten-kota-di-jawa-tengah-2016-ha-.html. 2 Desember 2019

Barnes, R.D. \& Rupert, E.C. 1994. Invertebrate Zoology. Sixth Edition, Sounders College Publishing, USA, pp. 350-380

Buchanan, J.B. 1984 Sediment Analysis. In: N. A. Holme and A. D. Mclntyre (Ed.). Methods for the study of marine benthos. Oxford: Blackwell Scientific Publications. pp. 41-65.

Carpenter, E.K \& Niem, V.H. 1998. The Living Marine Resource of The Wastern Central Pacific. Vol 1, Bivalves and Gastropods. FAO of the United Nations, $686 \mathrm{pp}$.

Dharma, B. 1992. Siput dan kerang Indonesia. Indonesian shells II. Verlagcusta Hemmen. Wiesbaden. Germany

Ernanto, R., Agustriani F. \& Aryawati, R. 2010. Struktur Komunitas Gastropoda Pada Ekosistem Mangrove di Muara Sungai Batang Ogan Komering Ilir Sumatera Selatan. Maspari Journal, 1:73-78. doi: 10.36706/maspari.v111.1128

Hutama, H.F.R., Hartati, R., \& Djunaedi, A. 2019. Makrozoobenthos Gastropoda pada Vegetasi Mangrove di Pesisir Utara, Semarang. Buletin Oseanografi Marina, 8(1):37-43, doi: 10.14710/buloma.v8i1.22453

Irwanto. 2006. Keanekaragaman Fauna pada Habitat Mangrove.Yogyakarta.

Krebs, C.J. 1989. Ecology: The Experimental Analysis of Distribution and Abundance. Third Edition. Harper and Row Publishers. New York 776 pp

Maslukah.I, Indrayanti, E. \& Rifai, A. 2014. Sebaran Material Organik dan Zat hara oleh Arus Pasang dan Surut di Muara Sungai Demaan, Jepara. IImu Kelautan, 19(4):189-194. doi: 10.14710/ik.ijms.19.4.189-194.

Nento, R., Sahami, F., \& Nursinar, S. 2013. Kelimpahan, Keanekaragaman dan Kemerataan Gastropoda di Ekosistem Mangrove Pulau Dudepo, Kecamatan Anggrek, Kabupaten Gorontalo Utara. Jurnal IImiah Perikanan dan Kelautan, 1(1):41-47.

Nontji, A. 1993. Laut Nusantara. Penerbit Djambatan. Jakarta

Nybakken, J.W. 1992. Biologi Laut Suatu Pendekatan Ekologi. Penerbit PT. Gramedia, Jakarta. 
Odum, E.P. 1993. Dasar dasar Ekologi. Edisi ke III. Diterjemahkan oleh Tjahjono, S. Gajah Mada University Press. Yogyakarta.

Plaziat, C.J. 1984. Mollusca Distribution in Mangal. Dr. W. Junk Published, Boston, pp.121-143

Sasekumar, A. 1974. Distribution on A Malayan Mangrove Shore. Journal of Animal Ecology, 43 (1):51-69

Wilhm, J.F. \& Dorris. 1986. Fundamental of Ecology. Danker Inc. pp.123-125 Working Paper No.153. Food and Agriculture Organization.

Wilhm, J.L. 1975. Biological Indicator of Pollution in River Ecological. Blackwell Scientific Publication. London. 